\title{
EXPLOITASI SEKS TERHADAP ANAK PEREMPUAN YANG MENJADI KORBAN PERDAGANGAN ORANG DI LOKASI PROSTITUSI
}

\author{
Yustinus Suhardi Ruman \\ Jurusan Psikologi, Fakultas Psikologi, BINUS University \\ Jln. K.H. Syahdan No. 9, Palmerah, Jakarta Barat 11480
}

\begin{abstract}
The special focus of this paper is the fenomen of girls who become sex workers. They are children under age of 18 year. This paper will show that the girls who become sex workers were human trafficking victim for sex commercial purpose. The beneficiaries of this exploitation are their parent, pimp, and those who live around of their life in prostitution location. Data is gathered by the researcher with Institute for Community Development and Social Advocacy (ICODESA) team which advocate girls as human trafficking victims in interview, observation and discussion. Child sex workers must be claimed as Prostituted Children. Psychologically they have not been able to identify rationally every decision they take; socially and economically they are victims that structurally force themselves trapped in human trafficking. They have no education, no skills needed for industry, and they are also powerless towards patriarchal local culture.
\end{abstract}

Keywords: child, sex workers, prostituted children

\begin{abstract}
ABSTRAK
Fokus artikel ini adalah fenomena anak perempuan yang menjadi pekerja seks. Mereka berusia di bawah 18 tahun. Artikel ini menunjukkan bahwa anak-anak perempuan yang menjadi pekerja seks adalah korban dari perdagangan perempuan untuk tujuan komersial seks. Pihak-pihak yang bertanggung jawab atas eksploitasi ini adalah orang tua, mucikari, dan mereka yang berada di sekitar lokasi prostitusi. Data dikumpulkan oleh penulis bersama team Institute for Community Development and Social Advocacy (ICODESA) mengadvokasi anak perempuan yang menjadi korban perdagangan orang dalam bentuk wawancara, observasi dan diskusi. Pekerja seks anak harus diakui sebagai Anak Yang Dilacurkan. Secara psikologis mereka belum dapat mendefenisikan secara rasional setiap keputusan yang mereka ambil, dan secara sosial dan ekonomi mereka adalah korban yang secara struktural mendesak mareka terjebak dalam perdagangan orang. Mereka tidak tidak dapat melanjutkan pendidikan, tidak memiliki ketrampilan yang dibutuhkan oleh dunia industri dan mereka juga tidak berdaya terhadap budaya lokal yang patriarkis.
\end{abstract}

Kata kunci: anak, pekerja seks, anak-yang-dilacurkan 


\section{PENDAHULUAN}

Prostitusi anak merupakan suatu fenomena yang menyebar di hampir semua negara terutama di Asia. United Nations Economic and Socail Commission for Asia and the Pacific pada tahun 1999 menerbitkan laporan penelitian yang dilakukan di Banglades, India, Nepal, Pakistan dan Srilangka tentang Penyimpangan dan eksploitasi seks anak dan remaja. Laporan itu menyebutkan bahwa banyak anak di Banglades mengalami kejahatan eksploitasi seksual. Anak-anak ini dibawah dari kampungkampung mereka dengan janji akan diberikan suatu pekerjaan di kota. Namun ketika sampai di kota anak-anak ini dijebak dalam perdagangan seks. Kasus-kasus serupa ditemukan juga di India, dan Nepal. Di India diperkirakan terdapat 270,000 sampai dengan 400.000 anak yang menjadi pekerja seks di India. Menurut CWIN (Child Workers in Nepal) setiap tahun kurang lebih 5000 sampai dengan 7000 anak perempuan dijual ke India dan diperkirakan terdapat 200.000 orang Nepal menjadi pekerja seks di India, $20 \%$ di antaranya berusia di bawah 16 tahun. Data-data yang dipaparkan ini hanya menggabarkan besaran masalah yang sempat dikuantifikasi, namun sebenarnya tidak dapat diragukan fenomena prostitusi anak masih jauh lebih besar dari apa yang sempat dicatat oleh badan-badan pemerintah dan NGO yang melakukan advokasi dan pendampingan terhadap anak perempuan yang dilacurkan.

Seperti yang terjadi pada negara-negara tersebut di atas di Indonesiapun tidak dapat disangkal bahwa banyak anak perempuan yang menjadi pekerja seks. Walaupun tidak ada data yang cukup menginformasikan jumlah yang akurat pekerja seks anak di Indonesia, Irwanto dari PKPM Atma Jaya, Jeffry Anwar dari Mitra Masyarakat Kota jakarta dan Mohamad Farid aktivis hak-hak anak Yogyakarta (Hendardi, 1988) memperkirakan 30 \% pekerja seks anak di Indonesia berusia di bawah 18 tahun. Prosentasi ini bila menggunakan perkiraan yang dilakukan oleh Jones, Sulistyaningsih \& Hull (1995) berarti 40.000 sampai dengan 70.000 orang anak perempuan dan bila menggunakan perkiraan data yang dibuat oleh Wanger \& Yatim (1997) berarti 150.000 perempuan di Indonesia yang menjadi pekerja seks.

\section{METODE}

Pada bulan Desember 2003 dan dilanjutkan pada tahun 2005-2007 penulis bersama team Institute for Community Development and Socia Advocacy (ICODESA) mengadvokasi Anak Perempuan yang menjadi korban Perdagangan orang untuk prostitusi di lokasi prostitusi. Pada periode ini penulis melakukan wawancara, observasi dan diskusi-diskusi. Oleh karena itu maka seluruh tulisan ini berasal dari wawancara, observasi dan diskusi yang intens yang penulis lakukan bersama dengan anak perempuan pekerja seks tersebut di salah satu lokasi prostitusi di Jakarta Utara. Demi kepentingan etika penelitian semua nama yang dicantumkan dalam seluruh uraian ini adalah nama samaran, bukan nama yang sebenarnya. Demikian juga nama lokasi prostitusi tidak dicantumkan di sini. Nama-nama yang sebenarnya baik orang maupun lokasi ada pada sekertarian Institute for Community Development and Social Advocacy (ICODESA) Jakarta.

\section{PEMBAHASAN}

\section{Deskripsi Konsep-Konsep Terkait}

\section{Konsep Anak}

Konvensi International Mengenai Anak sebagaimana yang tertuang dalam Konvensi Hak Anak (KHA) memberikan batasan usia pada anak yaitu mereka yang belum berumur 18. Konvensi ini memberikan batasan usia maksimal yang dapat dikategorikan dalam usia anak, tetapi tidak 
memberikan batasan yang tegas usia minimal yang dikategorikan sebagai usia anak. Untuk menjawab permasalahan apakah yang dimaksudkan dibawah usia 18 tahun itu termasuk anak yang berada dalam kandungan, KHA mengadopsi dua pandangan yakni: (1) anak yang masih dalam kandungan termasuk dalam pembatasan usia dibawah 18 tahun dan padangan; dan (2) yang dimaksudkan dalam usia dibawah 18 tahun tidak termasuk bayi yang masih dalam kandungan.

Di Indonesia defenisi mengenai anak dapat kita jumpai dalam Undang-Undang No. 23/2002 tentang Perlindungan Hak Anak. Undang-Undang ini mendefenisikan bahwa anaka adalah orang yang belum berusia 18 tahun, termasuk dalam pembatasan ini adalah anak yang masih dalam kandungan. Ada beberapa point yang dapat digarisbawahi dari pembatasan ini yakni: (1) Undang-Undang ini tidak membenarkan praktek aborsi; (2) dengan tidak membenarkan praktek aborsi, maka anak yang di dalam kandungan secara inherent memiliki hak untuk hidup, bertumbuh dan berkembang. Dan karena kondisinya yang masih harus bergantung pada orang lain pada mana ia bergantung, anak itu mendapat hak yang diberikan dan dilindungi oleh Undang-Undang yakni hak untuk mendapat perlindungan; dan (3) pembatasan usia dalam undang-udang ini tidak mengecualikan seseorang yang sudah menikah. Artinya walaupun seseorang sudah menikah, ia tetap dikategorikan anak dan mendapat hak-haknya sebagai anak seperti yang diatur dalam Undang-Undang ini.

\section{Perempuan}

Perempuan yang dimaksudkan dalam pembahasan ini lebih merupakan suatu kenyataan sosiologis yang dikatikan dengan status dan peran sosial dalam masyarakat yang berbeda dengan lakilaki. Sebagai kenyataan biologis pada dasarnya tidak ada masalah yang mendasar karena kenyataan itu lebih bersifat faktual yakni sebagai suatu keterberian yang tidak dapat ditolak.

Pendekatan-pendekatan feminis dalam menganalisa kenyataan sosiologis itu menyimpulkan bahwa relasi antara laki-laki dengan perempuan bersifat tidak adil. Ketidakadilan ini bukan merupakan suatu yang bersifat fungsional tetapi bersifat eksploitatif karena perempuan pada umumnya tidak memiliki akses kepada kekuasaan, prestise sosial dan hak-hak istimewa baik dalam ranah domestik seperti rumah tangga maupun pada arena publik yang lebih luas dalam masyarakat, pada hal kalau dilihat dari segi kontribusi peran perempuan sangat penting baik dalam wilayah domestik maupun publik. Namun perempuan sering dianggap sebagai elemen komplementer, pelengkap semata. Dalam konteks budaya patriarkat perempuan dilihat sebagai kelas sosial yang berada di bawah dan dieksploitasi oleh kelas sosial lainya yakni pria (Kuper \& Kuper, 2001). Eksisistensi perempuan dalam budaya seperti itu hanya ditentukan oleh fungsi biologisnya yang oleh Beauvoir dianggap sebagai mitos yang diciptakan oleh superioritas laki-laki dalam budaya patriarkat (Lie, 2005).

\section{Eksploitasi Seks Komersial Anak}

Terminologi eksploitasi pada dasarnya memiliki dimensi etis yang sangat luas yakni menyangkut setiap relasi antara manusia yang mana salah satu pihak mendapat keuntungan dengan memanfaatkan pihak yang lainnya. Di satu pihak yang dieksploitasi berada dalam posisi ketiadaan kapabilitas dalam aspek yang luas seperti tingkat pendidikan yang rendah, informasi yang kurang, tidak adanya kemungkinan alternative untuk dipilih atau secara singkat dapat dikatakan bahwa pihak yang dieksploitasi itu tidak memiliki sumber daya yang memungkinkan ia dapat dengan bebas menentukan pilihannya sendiri. Sumber daya itu dapat berupa sumber daya manusia, sumber daya social, sumber daya ekonomi dan bahkan sumber daya budaya yang membebaskan.

Pihak yang mengeksploitasi pada pihak yang lain memiliki kapabilitas yang lebih baik bila dibandingkan dengan pihak yang dieksploitasi. Kapabilitas ini bersumber pada sumberdaya manusia yang lebih baik, sumber daya social, dan sumber daya ekonomi. Referensi bagi sumber daya manusia bisa dilihat dalam latar belakang pendidikan, fisik dan semua sumber daya yang bersifat embeded pada manusia itu. Sedangkan sumber daya sosial dapat kita lihat dalam konteks jaringan yang dimiliki 
lebih luas, memiliki informasi yang cukup juga termasuk dalam hal ini menyangkut status dan peranan sosial yang dimainkan. Sumber daya ekonomi dapat berupa kemampuan keuangan yang dimiliki orang orang tersebut.

Perbedaan sumber daya dalam relasi antara manusia secara sosiologis merupakan sesuatu yang lumrah. Namun persoalannya adalah ketika salah satu pihak memanfaatkan sumber daya yang dimilikinya dengan menjadikan orang lain sebagai alat untuk mengakumulasi sumber daya yang dimilikinya atau untuk mendapat keuntungan. Relasi eksploitatif itu akan semakin jelas bila pihak yang diekploitasi di satu sisi tidak memiliki kapabilitas apapun baik untuk memilih maupun kemungkinan alternatif yang juga tidak ada, dan pada sisi yang lain kebutuhan-kebutuhan dasar mereka menuntut untuk dipenuhi bukan seminggu yang akan datang tetapi pada saat ini. Dan kondisi seperti ini individu atau kelompok yang tidak memiliki sumber daya itu sangat rentan terhadap eksploitasi.

Goodin (1988b) ${ }^{1}$ mengasumsikan empat kondisi yang menggambarkan ketergantungan yang dapat dieksploitasi. Pertama, hubungan itu bersifat asimetris, kedua kelompok subordinat sangat membutuhkan sumber daya yang hanya dimiliki oleh kelompok superordinat, ketiga posisi dari kelompok subordinat itu bergantung secara partikular kepada kelompok superordinat yang menyediakan sumber daya yang dibutuhkan dan keempat kelompok superordinat menikmati kemerdekaan untuk mengontrol sumeber daya yang sangat dibutuhkan oleh kelompok subordinat.

\section{Seks Komersial}

Terminologi komersial selalu berdimensi ekonomis yakni suatu transaksi yang bertujuan untuk memperoleh keuntangan. Pengertian ini memuat tiga komponen yang memainkan peran. Pertama ada dua pihak yang melakukan pertukaran, kedua ada sesuatu yang dipertukarkan dan ketiga ada alat sebagai media pertukaran. Dalam konteks pembahasan ini alat atau media pertukaran adalah seks. Pihak yang mengontrol seks akan mendapat sejumlah keuntungan seperti uang. Mendapatkan keuntungan uang adalah motivasi pihak yang mengotrol media atau alat pertukaran. Sedangkan pihak yang menyerahkan uang yang dibutuhkan mendapat kepuasan yang menjadi tujuannya.

\section{Eksploitasi Seks Komersial Anak}

Kalu kita berbicara tentang eksploitasi Seks Komersial Anak berarti kita menegaskan beberapa hal seperti: (1) anak merupakan kelompok subordinat yang tidak memiliki kapabilitas apapun. Mereka tidak memiliki kontrol atas diri mereka sendiri dan sumber daya yang menjadi kebutuhan dasar mereka. (2) Satu-satunya sumber daya yang ada pada anak adalah apa yang bersifat embeded ada pada mereka seperti usia yang masih muda dan seks yang masih dapat dijamin kesehatannya dan lain sebagainya. (3) Namun sumber daya ini dikontrol oleh mereka yang dapat menawarkan sumber daya yang menjadi kebutuhan anak. (4) Dalam konteks fenomena Eksploitasi Seks Komersial Anak, sumber daya yang bersifat embeded itu dikontrol oleh dua kelompok sekaligus yakni oleh kelompok yang menikmati jasa seks anak dan kedua mereka yang mendapatkan keuntungan ekonomi dari jasa seks anak yang dinikmati oleh kelompok penimat jasa seks anak. Kelompok-kelompok itu dapat diidentifikasi seperti para germo (produsen) di satu sisi dan klien (konsumen) pada sisi yang lainnya. Kedua kelompok memanfaatkan ketidakberdayaan anak untuk menentukan dirinya sendiri dan kondisi riil yang mereka hadapi saat ini yakni kebutuhan dasar yang harus dipenuhi.

Pada kongres dunia ke dua tentang penghapusan Eksploitasi Seks Komersial Anak di Yokohama, Jepang tanggal 17-20 Desember 2001, konggres mengadopsi lagi defensi yang sudah dirumuskan pada konggres dunia pertama 1996. Pada dasarnya konggres melihat bahwa eksplotasi

\footnotetext{
${ }^{1}$ Kutipan di atas diambil dari http://plato.edu/entries/exploitation/
} 
seks untuk komersial anak merupakan suatu kejahatan yang bersifat fundamental, suatu kejahatan terhadap hak anak.

"The commercial sexual exploitation of children is a fundamental violation of children's right. It
comprises sexual abuse by the adult and remuneration in cash or kind to the child or a third person or
persons. The child is treated as a sexual object and as a commercial object. The commercial sexual
exploitation of children constitutes a form of coercion and violence against children, and amounts to
forced labour and a contemporary form of slavery." (Trafficking in children for sexual purpose, 2001)

\section{Lingkaran Eksploitasi Terhadap Pekerja Seks Anak}

Berdasarkan desekripsi konsep di atas maka dalam paper ini anak yang menjadi pekerja seks dianggap sebagai Anak Yang Dilacurkan (AYLA). Ini berarti bahwa mereka dianggap sebagai korban korban. Pernyataan ini menimbulkan suatu pertanyaan sederhana siapakah mengorbankan mereka? Untuk menjawab pertannyaan ini kami menunjukan terlebih dahulu beberapa fenomena mengenai Anak Yang Dilacurkan.

Berdasarkan pengalaman penulis bersama ICODESA yang didukung oleh Plan Jakarta yang melakukan advokasi terhadap anak yang menjadi pekerja seks selama periode Desember 2003 dan dilanjutkan pada periode 2005 sampai dengan 2007, penulis dapat menyimpulkan bahwa anak perempuan yang menjadi pekerja seks berasal dari keluarga petani yang pada umumnya berasal dari desa-desa. Kecenderungan mereka tidak sempat mengenyam pendidikan yang cukup. Mereka juga kebanyakan tidak bertumbuh dalam keluarga yang utuh karena perceraian orang tua mereka. Ada orang tua mereka yang juga memiliki sejarah sebagai pekerja seks. Dan sebagian besar di antara mereka menikah dalam usia dini. Namun usia perkawinan mereka pada umumnya tidak bertahan lama lalu mereka cerai. Kondisi-kondisi seperti ini menjadi faktor kondusif untuk mendorong anak perempuan mudah terjebak untuk dimanfaatkan oleh orang lain di satu sisi dan pada sisi yang lain kebutuhan industri seks di kota telah menjadi faktor yang menarik anak perempuan dari desa-desa untuk datang ke kota.

Berdasarkan fenomena tersebut maka menjadi pekerja seks bukan merupakan suatu pilihan yang mengekspresikan subyek yang bebas melainkan simbol dari ketidakberdayaan mereka terhadap berbagai hal dalam hidup. Mereka tidak memiliki kemampuan atau dalam terminologi Amartya Sen (2000) mereka tidak memiliki kapabilitas untuk berpatisipasi secara bebas meraih setiap kesempatankesempatan sosial termasuk tentu dalam hal ini kesempatan untuk memenuhi kebutuhan dasar mereka secara normatif.

Kondisi-kondisi sosial tersebut di atas kondusif bagi anak perempuan untuk menjadi korban perdaganan orang. Protokol Perserikatan Bangsa-Bangsa untuk Mencegah, Memberantas dan Menghukum Perdagangan manusia, khususnya Perempuan dan Anak (dalam Rosenberg, 2003), Suplemen Konvensi Perserikatan Bangsa-Bangsa untuk Melawan Organisasi Kejahatan Lintas Batas mendefenisikan perdagangan Manusia sebagai berikut:

Perdagangan manusia adalah perekrutan, pengiriman, pemindahan, penampungan atau penerimaan seseorang dengan ancaman atau penggunaan kekerasan atau bentuk-bentuk lain dari pemaksaan, penculikan, penipuan, kebohongan, atau penyalagunaan kekuasaan atau posisi rentan atau memberi atau menerima pembayaran atau memperoleh keuntungan agar dapat memperoleh persetujuan dari seseorang yang berkuasa atas orang lain, untuk tujuan eksploitasi. Eksploitasi termasuk, paling tidak, eksploitasi untuk melacurkan orang lain atau bentuk-bentuk lain dari eksploitasi seksual, kerja atau pelayanan paksa, perbudakan atau praktik-praktik serupa perbudakan, perhambaan atau pengambilan organ tubuh. 
Kantor-kantor Perwakilan UNICEF di Eropa Tengah dan Eropa Timur pada bulan Mei 2003 (dalam Pedoman untuk perlindungan hak-hak anak korban perdagangan manusia) mengembangkan suatu defenisi khusus mengenai Perdagangan Anak. Mereka mendefenisikan Perdagangan Anak sebagai berikut: (1) perdagangan anak adalah tindakan perekrutan, transportasi, transfer, menyembunyikan atau menerima seorang anak dengan tujuan untuk eksploitasi baik di dalam maupun di luar suatu negara; (2) persetujuan dari korban untuk tujuan eksploitasi tidak relevan walaupun tidak digunakan cara-cara berikut: kekuatan, pemaksaan, penculikan, penipuan, penyalagunaan kekuasaan, atau tindakan yang dilakukan pada saat seseorang sedang dalam keadaan rentan atau sementara seseorang sedang berada di bawah kekuasaan orang lain; dan (3) seorang korban perdagangan anak (korban) anak adalah semua orang yang berusia di bawah 18 tahun.

Berdasarkan pengalaman penulis dalam mengadvokasi anak perempuan yang menjadi korban perdaganan orang untuk prostitusi ada dua kelompok utama yang dapat diidentifikasi sebagai pelaku yakni calo dan keluarga.

Kelompok pertama yakni para calo. Polanya adalah para calo datang menawarkan pekerjaan kepada anak perempuan baik melalui orang tua, teman ataupun langsung kepada anak perempuan calon tenaga kerja tersebut. Bila para calo langsung berhubungan dengan orang tua, orang tua anak perempuan itu kemudian memanggil anak perempuan lalu memberitahukan dan membujuk supaya anak perempuannya mau menerima tawaran itu. Reaksi anak perempuan ada yang langsung menerima namun ada yang menolaknya. Tetapi orang tua terus membujuk sampai akhirnya anak itu mau. Setelah anak mau orang tua menyerahkan anak kepada calo yang akan membawa mereka ke tempat tujuan.

Kedua, dijual langsung oleh orang tua kepada calo atau langsung kepada germo. Orang tua pada kelompok ini memiliki referensi yang jelas mengenai pekerjaan yang akan dilakukan oleh anak perempuan mereka yakni menjadi Pekerja Seks.

Dede dan Rena (bukan nama sebenarnya) misalnya dijual oleh ibu kandungnya sendiri untuk bekerja sebagai Pekerja seks. Untuk pekerjaan ini ibu Dede dan Rena mendapat Rp 8.000.000. Dede dibujuk ibunya untuk menjadi PS ketika ia berumur 14 tahun. Dede mengisahkan bahwa:

"Pagi-pagi waktu hendak berangka sekolah (kls. II SMP), Dede dipanggil ibu. Ibu bilang Dede, kamu kasihan ngga ama saudara kamu? Dede mempunyai saudara sepupu laki-laki yang tinggal bersama mereka. Pada hari itu sepupunya ini sedang berbaring dirumah sakit karena ditabrak kendaraan. Dokter menganjurkan untuk dioperasi. Dede menjawab bahwa Dede sangat sayang sama sepupunya ini. Ibu bilang saudaramu harus dioperasi, kalau tidak dioperasi dia akan mati. Kita membutuhkan uang yang banyak untuk biaya operasi. Ibu sekarang tidak mempunyai uang karena itu kamu harus berhenti sekolah dan mencari duit. Dede bilang sama ibu, Dede tidak mempunyai ijasah, apa mungkin Dede bisa dapat kerja. Ibu bilang nanti dia yang akan cari kerja. Ibu kemudian menelephone teman ibu. Setelah menelephon ibu menghantar Dede ke daerah kota. Sebelum berangkat Dede nanya kepada ibu, bu di sana nanti Dede kerja apa ? Ibu bilang Dede kerja di Karaoke dan temani laki-laki yang banyak duitnya. Kamu hanya temani mereka nyanyi, minum dan tidur setelah itu kamu akan dapat duit berjuta-juta. Masuk pertama ini saja nanti kamu akan mendapat duit Rp 4.000.000 kata ibu. Dede bilang sama ibu, kog tega amat si bu. Ibu bilang mau gimana lagi, ini jalan satu-satunya bagi kita dan hanya Dede yang bisa bantu ibu sekarang. Ibu terus membujuk Dede sampai akhirnya Dede mau juga.

\section{Motif}

Semua motif yang mendorong anak menerima tawaran kerja yang dijanjikan oleh para calo dan menuruti saran orang tua mereka untuk bekerja sebagai Pekerja seks umumnya sama yakni ingin membantu orang tua, orang tua terus membujuk, ingin mendapatkan uang dan membeli rumah. Orang tua memberi tahukan kepada anak perempuannya bahwa mereka memiliki utang, atau mereka sangat membutuhkan uang. 
Kondisi-kondisi yang digambarkan oleh orang tua, calo dan germo mendorong anak kemudian menaruh kasihan pada orang tua. Perasaan kasihan ini diimplementasikan dengan kesediaan anak menerima bujukan orang tua, calo dan germo untuk bekerja. Jelas di sini bahwa semua motif ini tidak ada yang berhubungan dengan kemauan dan inisiatif yang berasal dari dalam diri anak sendiri. Motifmotif yang mendorong mereka menerima tawaran kerja itu berasal dari luar yakni orang tua, calo dan germo.

Aas (bukan nama sebenarnya) menceriterakan bahwa, Aas sebenarnya ingin nerusin sekolah, tetapi hari Aas terima ijazah SD, ibu memanggil Aas ke kamar. Ibu nanya sama Aas, Aas kamu sayang nggak ama ibu dan bapa. Aas jawab, tentu saja Aas sayang ibu dan bapa. Lalu ibu bilang kalau sayang sama ibu dan bapa, Aas harus ikut bibi ke Jakarta untuk cari duit yang banyak. Aas nanya sama ibu emangnya di Jakarta kerja apaan bu ? ibu bilang layani tamu dan nemanin diwarung terus nanti Aas dapat duit banyak. Aas merasa terkejut mendengar ibu bilang begitu, tetapi Aas merasa sedih melihat ekonomi orang tua Aas.

\section{Tempat yang Menjadi Tujuan}

Beberapa tempat yang menjadi tujuan penjualan anak perempuan untuk dipekerjakan sebagai pekerja seks adalah Mangga Besar, Batam, Riau dan kota-kota besar lainnya. Namun hampir semua informan dalam penelitian ini sebagian besar mengakui bahwa mereka sebelum tiba di lokasi prostitusi mereka bekerja sebagai Pekerja Seks di hotel-hotel berbintang. Perpindahan dari hotel-hotel berbintang ke lokasi prostitusi di mulai ketika mereka pulang kembali ke kampung. Setelah beberapa hari di kampung mereka bertemu dengan calo, teman-teman lain yang membujuk mereka untuk bekerja di lokasi prostitusi.

Di lokasi prostitusi mereka merasa lebih bebas. Mereka sendiri yang melakukan transaksi dengan tamu, menyimpan sendiri uang hasil kerja mereka dan mereka dapat menolak tamu bila mereka tidak siap untuk melayani tamu. Hal ini berbeda ketika mereka menjadi pekerja seks di hotelhotel. Di hotel mereka tidak perlu mencari makan, membeli perlengkapan make up, sabun mandi dan bahkan pakaian-pakaian khusus untuk menerima tamu. Namun biaya yang harus mereka berikan adalah mereka tidak dapat menentukan sendiri kapan mereka harus beristirahat. Mereka terus dipaksa melayani tamu selama tamu masih terus datang, transaksipun dilakukan antara germo dengan tamu. Anak perempuan yang dilacurkan tidak dilibatkan sama sekali, kecuali mereka harus menerima tamu terus menerus.

Mereka juga tidak menyimpan sendiri uang hasil kerja mereka. Germo paling berkuasa, dialah yang menentukan semuanya termasuk menyimpan uang hasil kerja anak perempuan. Bahkan ada yang mengakui bahwa ketika mereka hendak pulang ke kampung germo menahan sebagian uang sebagai jaminan supaya mereka harus kembali lagi ke tempat itu.

\section{Eksploitasi Seks untuk Tujuan Komersial}

Berdasarkan uraian-uraian di atas jelaslah bahwa anak perempuan pekerja seks adalah Anak Yang Dilacurkan dan oleh karena itu juga tidak dapat diragukan bahwa mereka mengalami eksploitasi seks untuk tujuan komersial. Namun untuk lebih tegas bagaimana eksploitasi seks itu terjadi saya akan merinci pengalaman eksploitasi seks di hotel-hotel dan dilokasi prostitusi.

\section{Eksploitasi Seks di Hotel}

Pada umumnya anak perempuan yang menjadi pekerja seks di hotel-hotel seperti di Jakarta melayani laki-laki yang berasal dari Korea, Jepang Cina, Eropa dan Indonesia. Kesan bahwa pria-pria ini berasal dari kalangan berduit tidak dapat diragukan lagi. Hal ini ditunjukan bahwa biasanya anak perempuan yang baru datang dari kampung akan dinilai dengan harga yang sangat tinggi. Biaya ini 
muncul dari biaya yang dibayarkan oleh germo ke pada calo, biaya hotel dan fasilitas yang disiapkan oleh germo untuk anak perempuan yang dipekerjakan sebagai pekerja seks.

Anak-anak perempuan ini biasanya di masuk lebih dulu dalam kamar hotel atau duduk ditempat yang sudah disediakan secara khusus. Laki-laki yang hendak mendapatkan pelayanan seks mereka datang langsung bertransaksi dengan germo melalui kasir dan setelah itu memasuki kamar yang sudah disediakan di mana anak perempuan sudah ada di dalamnya. Ketika mereka masuk muncul ketidaknyamanan pada anak perempuan dan ketidaknyamanan ini menjadi semakin jelas ketika tamu asing itu meminta melakukan hubungan seks. Pada saat seperti ini anak perempuan menyampaikan penolakannya, memberontak, menangis, lalu pasrah tidak berdaya.

Setelah peristiwa pertama itu terjadi mereka memberitahukan pengalaman mereka dengan teman dan germo. Tetapi hampir semua mekanisme ini tidak menolong mereka. Mereka bahkan dimarahi oleh germo. Mereka diacam akan dilaporkan ke polisi. Pemaksaan ini dilakukan karena menurut germo anak perempuan harus membayar uang yang telah mereka berikan kepada calo atau orang tua anak perempuan. Uang yang dikeluarkan oleh germo untuk calo atau orang tua dianggap sebagai utang yang harus dibayar oleh anak perempuan. Inilah sebabnya mengapa seluruh transaksi dilakukan antara germo dengan tamu.

Jam kerja anak perempuan melayani tamu juga banyak, mereka dilarang istirahat dan bahkan bila mereka datang bulan mereka dipaksa minum obat supaya haidnya berhenti. Anak perempuan dipaksa melayani tamu sejumlah yang diinginkan oleh germo. Walaupun ada juga germo, atau pria yang hendak mendapatkan jasa seks mereka menaruh iba pada anak perempuan yang menangis dan memberontak sebagai mana kisah Wiwin (bukan nama sebenarnya) berikut ini, pengalaman itu hanya merupakan kekecualian yang langka. Wiwin mengisahkan bahwa:

"Suatu hari ada tamu yang baik sekali. Aku cerita tetang kejadian aku ditipu oleh germo ama tamu ini. Mendengar kisahku, tamu itu berjanji akan membawa aku keluar dari rumah ini. Keesokan harinya ia datang lagi, ia membawa aku keluar dari rumah itu dan bahkan mengurus semua kepulanganku ke Kediri. Aku nanya kepada orang itu kog kamu bisa mengeluarkan aku dari rumah ini. Orang itu bilang aku sudah kasih uang jaminan kepada mami. Perasaanku saat itu antara senang dan sedih. Senang karena bisa keluar dari rumah itu dan sedih kalau ingat kejadian di dalam rumah bordil itu. Aku hanya bisa ucapkan terima kasih kepada orang itu"

\section{Menjadi Fatalis}

Anak Perempuan Yang Dilacurkan (AYLA) akan dibebaskan dari penguasaan germo di hotel bila: (1) seluruh biaya yang dikeluarkan oleh germo ke pada calo sudah kembali; (2) bila germo sudah mendapat untung; dan (3) anak perempuan sudah tidak diminati lagi oleh tamu karena anak perempuan-anak perempuan pendatang baru. Pada saat seperti itu tidak ada halangan bagi anak perempuan untuk pulang ke kampung. Namun setelah mereka tiba dikampung mereka berhadapan dengan situasi kesulitan yang dialami oleh keluarga atau orang tua mereka, dan pada saat yang sama pengalaman-pengalaman mereka di dilacurkan di kota kembali hidup dalam kesadaran mereka. Kenangan buruk ini akan semakin kuat bila mereka menyadari bahwa tetangga mereka yang fasilitas rumahnya bagus adalah pekerja seks di Jakarta, Batam atau di kota-kota lainnya, atau mereka kenal bahwa dalam keluarga mereka ada salah satu anggota entah saudara jauh atau dekat pernah menjadi pekerja seks.

Situasi rumah, kenangan buruk yang baru saja menimpa, dan kesadaran tentang lingkungan sosial seperti itu kondusif membuat mereka terjebak dalam suatu keputusan fatalistik untuk menjadi Pekerja Seks tanpa pemberontakan sebagaimana yang mereka lakukan ketika pertama kali hal itu menimpa mereka di hotel-hotel besar di pusat kota besar. Pada saat seperti ini bila ada teman, calo atau bahkan keluarga dan germo yang mengajak mereka untuk kembali ke Jakarta mereka akan 
menerima tawaran itu dengan kesadaran penuh mengenai apa yang mereka akan lakukan di Jakarta nanti atau dilokalisasi.

Pengalaman-pengalaman eksploitasi seks seperti yang mereka alami di hotel-hotel di kota-kota besar pada dasarnya hampir sama yakni mereka harus melayani tamu walau lelah, masih mestruasi, sakit dan bahkan ada tamu yang tidak membayar. Eksploitasi jenis terakhir ini tidak mereka alami di hotel-hotel di kota besar karena seluruh transaksi dilakukan antara germo melalui kasir dengan tamu. Anak perempuan akan menerima upah jasa seks mereka pada akhir bulan. Sedangkan dilokasi prostitusi kalau ada tamu yang tidak bayar, maka beban biaya yang harus diberikan kepada germo harus ditanggung oleh anak perempuan pekerja seks itu sendiri. Paling sering eksploitasi seperti ini dilakukan oleh pacar-pacar mereka yang pada umumnya sudah menikah atau berkeluarga.

\section{Pengalaman Kekerasan}

Undang-Undang Penghapusan Kekerasan Dalam Rumah Tangga No.23/2004 mendefenisikan kekerasan dalam rumah tangga sebagai suatu perbuatan terhadap seseorang terutama perempuan, yang berakibat tibulnya kesengsaraan atau penderitaan secara fisik, seksual, psikologis, dan atau penelantaran rumah tangga termasuk ancaman untuk melakukan perbuatan, pemaksaan, atau perampasan kemerdekaan secara melawan hukum dalam ruang lingkup rumah tangga (pasal 1 bab II).

Bentuk-bentuk kekerasan dalam rumah tangga (KDRT) meliputi kekerasan fisik, psikis, seksual dan penelantaran rumah tangga. Kekerasan fisik adalah perbuatan yang mengakibatkan rasa sakit, jatuh sakit, atau luka berat (pasal 6). Kekerasan psikis adalah perbuatan yang mengakibatkan ketakutan, hilangnya rasa percaya diri, hilangnya kemampuan untuk bertindak, rasa tidak berdaya, dan/atau penderitaan psikis pada seseorang (pasal 7). Jenis kekerasan psikis ini ada yang menyebutnya dengan kekerasan simbolik (Darmoyo \&Riato, 2004). Kekerasan simbolik dapat berupa makian, dipelototi, dibentak, diancam, dituduh atau berbagai kekerasan yang mengakibatkan gangguan secara psikis. Kekerasan seksual adalah setiap perbuatan pemaksaan hubungan seksual (pasal 8) Sedangkan kekerasan ekonomi berupa penelantaran rumah tangga yang padahal menurut hukum yang berlaku ia wajib memberikan kehidupan, perawatan, atau pemeliharaan kepada orang tersebut (pasal 9 ayat 1).

Kekerasan yang dialami oleh anak perempuan pekerja seks dapat dikategorikan dalam beberapa aspek kekerasan yakni kekerasan fisik, kekerasan psikologis, kekerasan seksual dan kekerasan ekonomi. Kekerasan fisik dialami oleh anak perempuan pekerja seks seperti dipukul, dijambak, ditampar, ditendang, dilempar pakai botol bir, kursi, gelas minuman dan lain sebagainya. Kekerasan psikologis dapat berupa dicaci maki, diolok-olok, gosip yang menyebabkan anak terisolasi, diancam akan dilaporkan ke polisi atau dimasukan ke penjara. Kekerasan seks dapat berupa pemaksaan hubungan seks pada saat anak masih menstruasi, berhubungan seks dengan menggunakan aksesoris kelamin yang menyebabkan luka pada organ reproduksi anak perempuan, memaksa oral seks, sodomi dan menggunakan tangan serta sadisme seksual, dan dipaksa melakukan hubungan seks berkali-kali padahal kondisi anak perempuan sudah semaput.

Dan kekerasan ekonomi dapat berupa jeratan utang, penghasilan anak dipercayakan kepada germo namun anak tidak memiliki kebebasan untuk mengambil kembali uangya bahkan anak sampai harus berutang pada orang lain seperti teman atau tukang kredit yang bunga pinjamannya besar sampai $35 \%$. Kekerasan ekonomi akan nampak pula bila terjadi razia. Yang ditangkap pada umumnya anak perempuan. Mereka akan di bawa ke pos polisi, di sana mereka anak diinterogasi dan melakukan negosiasi tebusan sebagai biaya pembebasan mereka. Anak perempuan tidak memiliki uang. Pada kondisi seperti ini germo berlaku sebagai dewa penolong yang penuh tipu daya. Karena setelah itu anak perempuan dijerat oleh utang yang harus dibayarkan kepada 'sang dewa/dewi penolong'. Kekerasan ekonomi ini juga dapat dialami berupa penipuan dan pencurian. Untuk kasus penipuan dapat kita amati dalam kasus berikut. 


\begin{abstract}
"Suatu ketika Juju (bukan nama sebenarnya) berusia 18 tahun berhubungan seks klien selama semalaman. Keesokan harinya Juju diajak untuk ambil uang di ATM di Plaza Koja Tanjung Priok. Juju diminta untuk pinjam motor tukang ojek. Sampai di Plaza Koja, Juju diminta untuk tunggu di salah tempat, sampai berjam-jam menunggu sang klien tidak pulang lagi menemui Juju dia membawa pergi dengan motor pinjaman itu. Juju pulang kebali ke lokasi prostitusi dan melapor kejadian itu kepemilik motor, namun pemilik motor tetap meminta pertanggung jawaban Juju. Juju harus membyar motor itu sebesar Rp. 12 juta. Karena Juju tidak mempunyai uang sebanyak itu Juju berutang kepada germo.”
\end{abstract}

\title{
Drugs sebelum Berhubungan Seks
}

Anak perempuan dipaksa untuk mengkonsumsi pil-pil yang membangkitkan gairah seks mereka. Setelah mengkonsumi pil-pil itu agresifitas anak semakin meningkat dan mendorong mereka untuk berdansa, dance tanpa henti lalu pesta dunia maya ini berakhir diranjang tidur untuk berhubungan seks.

\section{Tertular Infeksi Menular Seksual dan HIV/AIDS}

Media penularan Infeksi Menular Seksual dan HIV/AIDS yang paling kodusif salah satunya adalah melalui hubungan seks. Hasil-hasil pemeriksaan oleh dokter ICODESA dengan peralatan yang seadanya menunjukan bahwa $3 / 4$ anak perempuan mengalami infeksi menular seksual. Keadaan ini hanya merupakan fenomena gunung es karena tidak semua gejala IMS langsung dapat diiderai kecuali melalui peralatan yang memadai seperti laboratorium. Sedangkan mengenai kasus HIV/AIDS belum ada informasi yang memadai dan akurat, tetapi seorang Peer Educator ICODESA-Plan pada tahun 2006 didiagnosa mingindap HIV/AIDS oleh YSA Foundation. Berapa bulan setelah diagnosa itu dia meninggal. Berdasarkan VCT dan informasi dari teman-teman sebanya ODHA ini memiliki riwayat pelaku seks aktif dengan para pekerja seks dilokasi prostitusi.

\section{Kehamilan, Aborsi dan Pemeliharaan bayi}

Salah satu masalah serius yang dihadapi oleh anak perempuan yang dilacurkan adalah masalah kehamilan. Masa kehamilan merupakan masa yang penuh dengan ketegangan. Siapa yang akan bertanggungjawab? Hamil bukan saja menimbulkan ketegangan mengenai saat ini, tetapi juga suatu beban baru bakal akan lahir di bulan-bulan yang akan datang. Dalam ketegangan seperti ini ada anak perempuan memutuskan lebih baik untuk aborsi. Sedangkan bagi mereka tidak aborsi atau aborsi tetapi gagal, bayi-bayi yang akan lahir dari mereka akan dipelihara oleh germo atau ada juga oleh tukang ojek. Aborsi dilakukan oleh dukun, dan dokter atau mereka berusaha mengkonsumsi pil dan makanan yang mereka yakini dapat mengguggurkan bayi yang ada dalam kandungan mereka.

Anak-anak para pekerja seks yang hidup-tumbuh-kembang di lokasi prostitusi terdiri dari anak yang orang tuanya mantan pekerja seks dan orang tuanya masih aktif sebagai pekerja seks. Perilaku anak-anak dari mantan pekerja seks atau yang ibunya masih aktif sebagai pekerja seks menunjukan kecenderungan deviasi. Anak-anak pria yang sudah berusia remaja pada umumnya sudah melakukan hubungan seks dengan pekerja seks. Pergaulan mereka sehari-haripun cenderung kasar dan suka berbohong. Sedangkan remaja putri sering mendapat pelecehan seksual yang dilakukan oleh pria hidung belang yang datang ke lokasi prostitusi. Di rumahpun mereka sering mendapat kekerasan fisik dan psikis yang dilakukan oleh orang tua mereka. Orang tua mereka cenderung membiarkan penyimpangan prilaku yang dilakukan oleh anak-anak mereka.

\section{Hilangnya Hak untuk Menentukan Diri Sendiri}

Hilangnya hak untuk menentukan diri sendiri dapat kita lihat pada aturan yang terdapat dalam beberapa wisma atau rumah bordil di lokasi prostitusi. Aturan ini dibuat oleh germo terhadap perempuan dan anak perempuan yang hidup dalam penguasaannya. Perempuan dan anak perempuan 
dilarang bergaul dengan teman-teman mereka yang tingga di wisama lain. Bahkan pedagang sering menjajakan danganganya dari satu wisam ke wisma lannya dilarang untuk menjajakan dagangannya di wisam itu. Kalau ada perempuan dan anak perempuan yang mau ke pasar atau ke mall mereka harus diantar oleh tukang ojek yang sudah disediakan secara khusus oleh germo. Perempuan dan anak perempuan tidak memiliki kebebasan untuk memilih tukang ojek atau sarana transportasi lainnya. Atau bahkan yang akan mengantar mereka adalah germo sendiri atau bartender. Selain oleh para germo, kehidupan anak perempuan yang dilacurkan ini diawasi ketat oleh para bartender, petugas keamanan dan bahkan oleh para pengurus RT dan RW di mana lokasi prostitusi tersebut berada. Bartender adalah orang kepercayaan germo. Bartender memiliki tugas untuk mengawasi perempuan dan anak perempuan yang tinggal dalam wisma mereka.

Bartender juga mempunyai tugas untuk membeli dan membagi minuman. Kalau germo lagi tidak ada di wisma, bartender mendapat kepercayaan penuh untuk mengelolah seluruh kegiatan yang ada di wisma. Tidak jarang bartender juga bertugas untuk mendatangkan anak-anak baru yang marketable, yang lebih diperkirakan akan dapat menarik tamu lebih banyak.

Lokasi prostitusi yang menjadi lokasi advokasi ICODESA di jaga ketat oleh petugas keamanan seperti Hansip. Mereka berjaga selama 24 jam, mengunjungi setiap wisma untuk memeriksa keamanan secara keselurahan dan menagih uang keamanan setiap malam dari satu wisma ke wisma lain. Kalau mereka menemukan persoalan, misalnya ada tamu yang tidak membayar, tamu yang mabuk dan mencuri maka pihak keamanan langsung turun tangan untuk menyelesaikannya. Selain itu pihak keamanan juga berkeliling untuk menagih iuran keamanan sebesar Rp.5000 per perempuan dan anak perempuan yang dilacurkan untuk setiap minggu. Uang ini digunakan untuk membayar gaji petugas keamanan. Hal lain yang terpenting adalah memberitahukan kepada semua wisma kalau akan ada razia dari pihak kepolisian.

\section{PENUTUP}

Berdasarkan uraian di atas nampak jelas bahwa pekerja seks anak harus diperlakukan sebagai Korban dan tidak sebagai Pekerja Seks. Dalam konteks ini, maka mereka harus diakui sebagai Anak Yang Dilacurkan. Tesis ini memiliki implikasi moral, yakni adalah tidak pantas mereka diperlakukan sebagai Pekerja Seks yang pada umumnya di anggap sebagai penyakit masyarakat. Anak yang Dilacurkan ini telah menjadi korban dari ketidakberdayaan baik secara psikologis, sosial dan ekonomi. Secara psikologis mereka belum dapat mendefenisikan secara rasional setiap keputusan yang mereka ambil, dan secara sosial dan ekonomi mereka adalah korban yang secara struktural mendesak mareka terjebak dalam perdagangan orang. Mereka tidak tidak dapat melanjurkan pendidikan, tidak memiliki ketrampilan yang dibutuhkan oleh dunia industri dan mereka juga tidak berdaya terhadap budaya lokal yang patriarkis.

\section{DAFTAR PUSTAKA}

Darmoyo, S., \& Riato, A. (2004). Trafficking anak untuk pekerja rumah tangga. Jakarta: PKPM UAH.

Hendardi, A. (1988). Ringkasan analisa situasi anak yang membutuhkan perlindungan khusus. Jakarta: PKPM Atma Jaya, Departemen Sosial dan UNICEF.

Kuper, A., \& Kuper, J. (2001). Ensiklopedi ilmu-ilmu sosial. (Harismunandar, terj.). Jakarta: Raja Grafindo Persada. 
Lie, S. (2005). Pembebasan tubuh perempuan: Gugatan etis Simone de Beauvoir terhadap budaya patriarkat. Jakarta: Grasindo.

Republik Indonesia. (2004). Undang-Undang Republik Indonesia nomor 23 tahun 2004 tentang penghapusan kekerasan dalam rumah tangga. Jakarta: Lembar Negara Republik Indonesia Nomor 4419.

Rosenberg, R. (2003). Perdagangan perempuan dan anak di Indonesia. Jakarta: USAID, ICMC, SOLIDARITY CENTER.

Sen, A. (2000). Inequality reexamined. New York: Russell Sage Foundation.

United Nations Economic and Social Commission for Asia and the Pacific. (1999). Sexually abused and sexually explited children and youth In South Asia: A qualitative assessment of their health needs and available services. New York: United Nations.

UNICEF. (n.d.). Pedoman untuk perlindungan hak-hak anak korban perdagangan manusia.

Trafficking in children for sexual purpose. (2001). A Contribution of UNICEF To The $2^{\text {nd }}$ World Conggress Against Commercial Sexual Exploitation of Children, Yokohama, Japan, 17-20 Desember 2001. 